\title{
ANALISIS FAKTOR YANG BERHUBUNGAN DENGAN KETERBUKAAN STATUS HIV SEROPOSITIF WANITA PENDERITA HIV/AIDS TERHADAP PASANGAN SEKSUAL DI LSM VICTORY YOGYAKARTA
}

\section{HIV DISCLOSURE STATUS AND FACTORS AMONG WOMEN TO THEIR SEXUAL PARTNER IN LSM VICTORY YOGYAKARTA}

\author{
Dwi Kartika Rukmi1*, Miftafu Darussalam²
}

\begin{abstract}
*1Program Studi Keperawatan Fakultas Kesehatan Universitas Jenderal Achmad Yani Yogyakarta, Kampus II Jl. Brawijaya Ring Road Barat Ambarketawang, Gamping, Sleman, Yogyakarta Email: kartikarukmi@gmail.com, Indonesia 2Program Studi Keperawatan Fakultas Kesehatan Universitas Jenderal Achmad Yani Yogyakarta, Kampus II Jl. Brawijaya Ring Road Barat Ambarketawang, Gamping, Sleman, Yogyakarta, Indonesia
\end{abstract}

\begin{abstract}
Background: The disclosure of women's HIV status toward their sexual partners is an important issue that should be regarded as one of the efforts to prevent and control the spread of HIV. Research on the disclosure of seropositive HIV status as well as women-related factors in Indonesia, especially Yogyakarta is only a few.

Objective: The purpose of this study is to analyse a factor related to the growth of HIV-positive female HIV/AIDS to sexual partners in LSM Victory Yogyakarta

Methods: This is a correlational descriptive research along with its cross-sectional approach on 329 women with HIV/AIDS at the Victory Plus NGO from June to July 2016. This research used a purposive sampling method and a questionnaire as the data collection technique. The bivariate analysis test was undertaken by using a chi square and multivariate test along with a logistic regression.

Result: The multivariate analysis and logistic regression show five independent variables related to the disclosure of seropositive HIV status of women with HIV/AIDS toward their sexual partners, namely ethnicity $(\mathrm{aOR}=36,859 ; 95 \% \mathrm{Cl} ;(6,544-207,616))$ religion $(\mathrm{aOR}=0,255 ; 95 \% \mathrm{Cl} ;(0,075-0,868))$, discussion with partners prior to the HIV test $(\mathrm{aOR}=0,069 ; 95 \% \mathrm{Cl} ;(0,065-0,438))$, types of sexual partners $(\mathrm{aOR}=0.191$; $95 \% \mathrm{Cl} ;(0.082-0,445))$ and knowledge on the partners' HIV status $(\mathrm{aOR}=0.036 ; 95 \% \mathrm{Cl} ;(0.008-0.160)$ ). The highest level of reason for seropositive HIV women not to be open about their partners' status is the fear of being rejected by their partners and the environmental stigma of HIV AIDS disease.

Conclusion: The disclosure of seropositive HIV status in women with HIV/AIDS in the Victory Plus NGO of Yogyakarta was $79.4 \%$ or classified as a high category with some related factors such as ethnicity, religion, discussion with partners prior to the HIV test, types of partners and knowledge on the partners' HIV status.
\end{abstract}

Keywords: Women, HIV, Disclosure, Sexual Partner.

\section{PENDAHULUAN}

Infeksi dari Human Immunodeficiency

Virus (HIV) serta penderita Acquired Immuno

Deficiency Syndrome (AIDS) yang semakin

bertambah merupakan tantangan tersendiri

untuk dunia kesehatan maupun

kemanusiaan. $^{1}$ Berbagai macam strategi

sudah dilakukan untuk mengontrol penyebaran HIV/AIDS antara lain dengan abstinence, kondom, dan penggunaan jarum suntik steril dengan tingkat keberhasilan yang beragam di berbagai negara. ${ }^{2}$ Metode lain yang digunakan adalah penggunaan antiretoviral yang sudah dikembangkan sejak tahun 1996 kepada penderita HIV supaya 
dapat bertahan hidup lebih lama dan infeksi HIV tidak berkembang menjadi AIDS. ${ }^{3}$

Maraknya penggunaan antiretroviral untuk menekan perkembangan HIV memunculkan kondisi di mana orang yang terinfeksi HIV dan terlihat sehat akan semakin bertambah namun tetap berpotensi untuk menginfeksi orang lain. ${ }^{3}$ Penyebaran HIV di Indonesia saat ini paling banyak ditularkan melalui hubungan seks heteroseksual (50\%). ${ }^{4}$ Besarnya angka penularan HIV melalui hubungan seksual salah satunya disebabkan karena banyak penderita HIV positif yang melakukan seks tidak aman dengan orang yang tidak pernah terinfeksi sebelumnya, mengabaikan status pasangan seksual, dan tidak terbuka kepada pasangan seksualnya mengenai statusnya padahal mereka sadar dapat menjadi sumber infeksi terkait status HIV yang dideritanya. ${ }^{5}$

Saat seseorang terinfeksi HIV maka dia harus mempertimbangkan beberapa hal antara lain tentang kematian dan keputusan untuk memberitahukan penyakitnya kepada orang lain baik teman, rekan kerja, keluarga, dan terutama kepada pasangan seksual. ${ }^{6}$ Keterbukaan akan status HIV seropositif pada wanita kepada pasangan seksualnya adalah hal penting yang harus diperhatikan sebagai salah satu upaya untuk mencegah dan mengontrol penyebaran $\mathrm{HIV}^{7}$

Keterbukaan status HIV seropositif memiliki efek dua sisi yang berlawanan, di satu sisi keterbukaan status HIV positif dapat memotivasi pasangan seksual untuk melakukan Voluntary Counseling and Test (VCT), mengurangi perilaku yang berisiko, serta meningkatkan support untuk taat terhadap pengobatan ART (Anti Retroviral Therapy), di sisi lain keterbukaan status HIV positif dapat menyebabkan wanita HIV seropositif mengalami beberapa hal yang tidak menyenangkan seperti disalahkan, diskriminasi, penolakan, depresi, kehilangan dukungan ekonomi, dan hancurnya hubungan keluarga. ${ }^{8,9,10}$ Semua hal tidak menyenangkan tersebut yang membuat wanita HIV seropositif memilih untuk tidak terbuka mengenai statusnya dan berakibat pada tidak tertanganinya kondisi infeksi HIV pasien, serta buruknya hasil pengobatan HIV yang sedang dijalaninya. ${ }^{7}$ Beberapa penelitian menyebutkan bahwa faktor sosiodemografi dan status ekonomi, faktor individu dan pasangan, serta faktor terkait kesehatan, berhubungan dengan keterbukaan status pasien HIV. ${ }^{7}$ Wanita Asia umumnya seperti di Indonesia masih menganggap bahwa keterbukaan status terinfeksi HIV masih menjadi sesuatu yang rumit terkait dengan budaya dan nilai gender yang berlaku. ${ }^{11}$

Yogyakarta menduduki peringkat ke 13 untuk jumlah penderita HIV/AIDS di Indonesia. ${ }^{4}$ Penderita HIV/AIDS di Yogyakarta sendiri sampai dengan triwulan I tahun 2015 berjumlah 3106 orang dan Victory Plus adalah Lembaga Swadaya 
Masyarakat (LSM) yang bergerak dalam penanganan dini HIV dan AIDS terbesar di Yogyakarta, LSM ini juga memberikan dukungan kepada Orang dengan HIV dan AIDS (ODHA) melalui berbagai macam programnya. Pada bulan Februari 2016 di LSM Victory Plus tercatat ada 742 wanita dengan HIV/AIDS.

Penelitian mengenai keterbukaan status HIV seropositif serta faktor-faktor yang berhubungan pada wanita di Indonesia masih sedikit sekali. Bahkan penelitian sejenis di Yogyakarta belum pernah dilakukan.

Tujuan penelian ini adalah mengidentifikasi gambaran keterbukaan status HIV seropositif pada wanita penderita HIV/AIDS terhadap pasangan seksualnya. Mengetahui hubungan antara suku, usia, pekerjaan, status pernikahan, agama, pendidikan, lama waktu sejak terdiagnosis, diskusi dengan pasangan sebelum tes HIV, lama menjalani ART, ketaatan terhadap ART, tipe pasangan seksual, pengetahuan tentang status HIV pasangan seksual, tinggal serumah dengan pasangan, lama waktu tinggal bersama pasangan, dan penggunaan kondom dengan keterbukaan status HIV seropositif pada wanita penderita HIV/AIDS terhadap pasangan seksualnya di Yayasan Victory Plus Yogyakarta

\section{BAHAN DAN CARA PENELITIAN}

Penelitian deskriptif analitik dengan pendekatan cross sectional. Sampel yang digunakan 329 wanita HIV seropositif dengan kriteria inklusi semua wanita dewasa (usia $\geq$ 18 tahun) penderita HIV/AIDS yang memiliki pasangan seksual dan pernah/sedang menjalani ART. Kriteria ekslusi adalah wanita penderita HIV/AIDS dengan orientasil bisekseksua/lesbian. Penelitian dilakukan di Victory Plus NGO Yogyakarta pada Juni Agustus 2016 dengan menggunakan kuesioner.

Analisis data univariat dengan analisis deskriptif, analisis data bivariat dengan chi square, dan analisis data multivariat dengan uji regresi logistik ganda.

\section{HASIL DAN PEMBAHASAN}

Hasil penelitian adalah sebagai berikut:

Tabel 1. Data Sosiodemografi Wanita Penderita HIV/AIDS

\begin{tabular}{|c|c|c|c|}
\hline \multirow{3}{*}{$\begin{array}{l}\text { NO } \\
1\end{array}$} & Variabel & $\sum$ & $\%$ \\
\hline & $\begin{array}{l}\text { Suku } \\
\text { Jawa } \\
\text { Non Jawa } \\
\text { Sunda (20), Batak (4) } \\
\text { Sulawesi (2),Kupang (2) }\end{array}$ & $\begin{array}{c}301 \\
28\end{array}$ & $\begin{array}{c}91.5 \\
8.5\end{array}$ \\
\hline & Total & 329 & 100 \\
\hline 2 & $\begin{array}{l}\text { Umur } \\
<25 \text { Tahun } \\
\geq 25 \text { Tahun }\end{array}$ & $\begin{array}{c}37 \\
292 \\
\end{array}$ & $\begin{array}{l}11.2 \\
88.8\end{array}$ \\
\hline & Total & 329 & 100 \\
\hline 3 & $\begin{array}{l}\text { Pekerjaan } \\
\text { Tidak Bekerja } \\
\text { Bekerja }\end{array}$ & $\begin{array}{l}154 \\
175 \\
\end{array}$ & $\begin{array}{l}46.8 \\
53.2 \\
\end{array}$ \\
\hline & Total & 329 & 100 \\
\hline 4 & $\begin{array}{l}\text { Status Pernikahan } \\
\text { Single } \\
\text { Belum Menikah (64) } \\
\text { Janda (71) } \\
\text { Menikah }\end{array}$ & 135 & 59 \\
\hline & Total & 329 & 100 \\
\hline 5 & $\begin{array}{l}\text { Agama } \\
\text { Islam } \\
\text { Non Islam } \\
\text { Kristen (22) Katholik (27) } \\
\text { Hindhu (9) }\end{array}$ & $\begin{array}{c}271 \\
58\end{array}$ & $\begin{array}{l}82.4 \\
17.6\end{array}$ \\
\hline & Total & 329 & 100 \\
\hline
\end{tabular}




\begin{tabular}{llcc}
\hline \hline 6 & $\begin{array}{l}\text { Pendidikan } \\
\text { Pendidikan Dasar } \\
\text { Tidak Sekolah (2) } \\
\text { SD (48),SMP (103) }\end{array}$ & 153 & 46.5 \\
& & \\
Pendidikan Lanjut & & \\
SMA (141), PT (35) & 176 & 53.5 \\
\hline Total & 329 & 100 \\
\hline
\end{tabular}

Tabel 2. Status Kesehatan dan Faktor Terkait Status Kesehatan Wanita Penderita HIV/AIDS

\begin{tabular}{|c|c|c|c|}
\hline NO & Variabel & $\sum$ & $\%$ \\
\hline \multirow[t]{4}{*}{1} & Lama Diagnosis & & \\
\hline & $<2$ Tahun & 123 & 37.4 \\
\hline & $\geq 2$ Tahun & 206 & 62.6 \\
\hline & Total & 329 & 100 \\
\hline \multirow[t]{4}{*}{2} & Diskusi Pasangan & & \\
\hline & Tidak & 144 & 43.8 \\
\hline & $\mathrm{Ya}$ & 185 & 56.2 \\
\hline & Total & 329 & 100 \\
\hline \multirow[t]{4}{*}{3} & Program ART & & \\
\hline & $<1$ Tahun & 100 & 30.4 \\
\hline & $\geq 1$ Tahun & 229 & 69.6 \\
\hline & Total & 329 & 100 \\
\hline \multirow[t]{4}{*}{4} & Ketaatan ART & & \\
\hline & Tidak & 39 & 11.9 \\
\hline & $\mathrm{Ya}$ & 290 & 88.1 \\
\hline & Total & 329 & 100 \\
\hline
\end{tabular}

Tabel 3. Sexual Experiences dan Faktor Terkait Sexual Experiences

\begin{tabular}{|c|c|c|c|}
\hline \multicolumn{4}{|c|}{ Terkait Sexual Expenences } \\
\hline \multirow{4}{*}{$\frac{\text { NO }}{1}$} & Variabel & $\Sigma$ & $\%$ \\
\hline & $\begin{array}{l}\text { Tipe Pasangan } \\
\text { Seksual }\end{array}$ & & \\
\hline & Casual & 92 & 28 \\
\hline & Steady & 237 & 72 \\
\hline & Total & 329 & 100 \\
\hline \multirow[t]{4}{*}{2} & $\begin{array}{l}\text { Pengetahuan Ttg } \\
\text { Status HIV Pasangan }\end{array}$ & & \\
\hline & Tidak & 121 & 36.8 \\
\hline & Ya & 208 & 63.2 \\
\hline & Total & 329 & 100 \\
\hline \multirow[t]{4}{*}{3} & Tinggal Serumah & & \\
\hline & Tidak & 96 & 29.2 \\
\hline & Ya & 233 & 70.8 \\
\hline & Total & 329 & 100 \\
\hline \multirow[t]{4}{*}{4} & $\begin{array}{l}\text { Lama Tinggal } \\
\text { Serumah }\end{array}$ & & \\
\hline & $\begin{array}{l}\text { Tidak serumah } /<1 \\
\text { tahun }\end{array}$ & 137 & 41.6 \\
\hline & $\geq 1$ tahun & 192 & 58.4 \\
\hline & Total & 329 & 10 \\
\hline \multirow[t]{4}{*}{5} & $\begin{array}{l}\text { Penggunaan } \\
\text { Kondom }\end{array}$ & & \\
\hline & Tidak & 224 & 68.1 \\
\hline & & 105 & 31.9 \\
\hline & Total & 329 & 100 \\
\hline
\end{tabular}

Tabel 4. Keterbukaan Status HIV Seropositif terhadap Pasangan Seksual

\begin{tabular}{|c|c|c|c|}
\hline NO & Variabel & $\sum$ & $\%$ \\
\hline \multirow[t]{4}{*}{1} & $\begin{array}{l}\text { Keterbukaan Status } \\
\text { HIV }\end{array}$ & & \\
\hline & Tidak & 67 & 20.4 \\
\hline & Ya & 262 & 79.4 \\
\hline & Total & 329 & 100 \\
\hline \multirow[t]{6}{*}{2} & Waktu Terbuka & & \\
\hline & Saat itu juga setelah & 14 & 5,4 \\
\hline & Kurang dari 1 bulan & 34 & 12,9 \\
\hline & $1-6$ bulan & 98 & 37,4 \\
\hline & Lebih dari 6 bulan & 116 & 44,3 \\
\hline & Total & 262 & 100 \\
\hline \multirow[t]{5}{*}{3} & Waktu Pendekatan & & \\
\hline & $\leq 1$ minggu & 14 & 5,4 \\
\hline & $\leq 1$ bulan & 84 & 32 \\
\hline & $>1$ bulan & 164 & 62,6 \\
\hline & Total & 262 & 100 \\
\hline
\end{tabular}

4 Waktu terbuka dan

ART

$\begin{array}{lll}\text { Sebelum ART } & 48 & 18,3\end{array}$

Saat ART

$214 \quad 81,7$

\begin{tabular}{ccrc}
\multicolumn{2}{c}{ Saat ART } & 214 & 81,7 \\
\hline & \multicolumn{1}{c}{ Total } & 262 & 100 \\
\hline 5 & Pengaruh Untuk & &
\end{tabular}

Terbuka

Dukungan Teman $\quad 80 \quad 30,5$

$\begin{array}{lll}\text { Media Massa } & 2 & 0,8\end{array}$

Orang Lain Terbuka $\quad 146 \quad 55,7$

Diri Sendiri $\quad 10 \quad 3,8$

\begin{tabular}{ccc} 
Pasangan & 24 & 9,2 \\
\hline Total & 262 & 100
\end{tabular}

$6 \quad$ Alasan Untuk Terbuka

Dukungan pasangan $202 \quad 77,1$

Mengurangi penularan $28 \quad 10,6$

$\begin{array}{lll}\text { Penanganan untuk } & 4 & 1,5\end{array}$

pasangan

$\begin{array}{lll}\text { Supaya taat ARV } & 12 & 4,6\end{array}$

Tanggung jawab pribadi $\quad 16 \quad 6,2$

\begin{tabular}{cccc} 
& Tanggung jawab pribadi & 16 & 6,2 \\
\hline & Total & 262 & 100 \\
\hline 7 & Alasan Tidak Terbuka &
\end{tabular}

Ditolak pasangan $\quad 30 \quad 44,7$

Mempermalukan $\quad 10 \quad 14,9$

keluarga

Tidak Pintar Komunikasi $\quad 1 \quad 1,5$

Takut stigma $\quad 24 \quad 35,9$

\begin{tabular}{ccc} 
Disakiti pasangan & 2 & 3 \\
\cline { 1 - 2 } & 67 & 100
\end{tabular}

Analisis Faktor Yang Berhubungan dengan Keterbukaan Status HIV Seropositif Wanita Penderita HIV/AIDS Terhadap Pasangan

Seksual di LSM Victory, Yogyakarta

Dwi Kartika Rukmi, Miftafu Darussalam

MIK P-ISSN 2252-3413, E-ISSN 2548-6268 
Table 5 Hasil Akhir Analisis Multivariat

Sig. $\operatorname{Exp(B)} \quad \mathrm{Cl} 95 \%$ for EXP

(B)

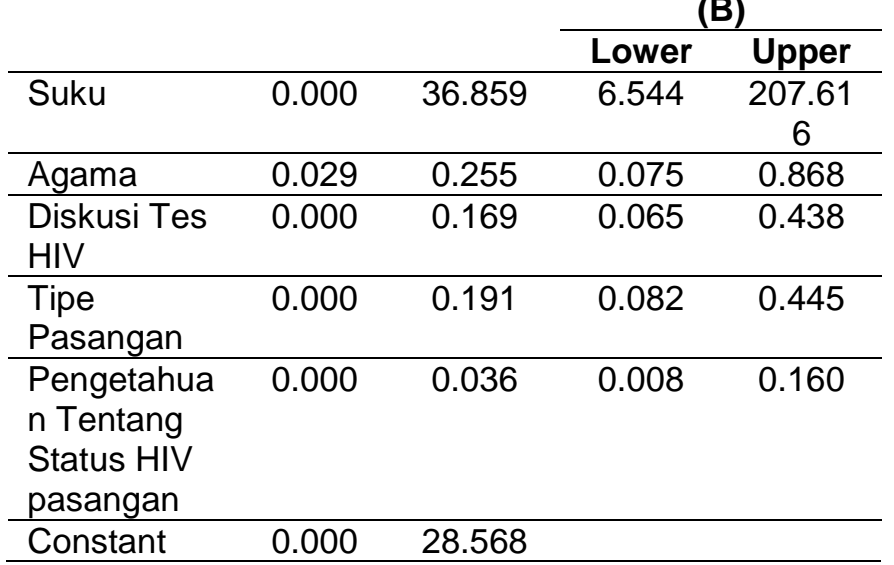

Hasil penelitian analisis multivariat didapatkan bahwa, ada lima variabel independen yang berhubungan terhadap keterbukaan status HIV seropositive wanita penderita HIV/AIDS terhadap pasangan seksualnya yaitu suku (aOR =36,859; $95 \% \mathrm{Cl}$; $(6,544-207,616))$, agama $(\mathrm{aOR}=0,255$; 95\% $\mathrm{Cl} ; \quad(0,075-0,868))$, diskusi dengan pasangan sebelum tes HIV ( $\mathrm{aOR}=0,069$; 95\%Cl; $(0,065-0,438)$ ), tipe pasangan (aOR $=0,191 ; \quad 95 \% \mathrm{Cl} ; \quad(0,082-0,445))$ dan pengetahuan tentang status HIV pasangan $(\mathrm{aOR}=0,036 ; \quad 95 \% \mathrm{Cl} ; \quad(0,008-0,160))$. Kekuatan hubungan dari yang terbesar ke yang terkecil adalah suku, agama, diskusi dengan pasangan sebelum tes HIV, tipe pasangan dan pengetahuan tentang status HIV pasangan.

\section{PEMBAHASAN}

Berdasarkan hasil uji analisis multivariate regresi logistik dari tabel 5 didapatkan hasil bahwa variabel suku
(aOR=36,859;95\%Cl;(6,544-207,616)) dan agama $\quad(\mathrm{aOR}=0,255 ; 95 \% \mathrm{Cl} ;(0,075-0,868))$ merupakan variabel yang berhubungan dengan keterbukaan status HIV seropositif. Hasil penelitian mengenai adanya hubungan antara agama dan suku dengan keterbukaan status HIV pernah diungkapkan oleh Seid et al $(2012)^{12}$ dalam penelitiannya. Namun dalam penelitian ini, peneliti belum dapat membahas secara lebih dalam karena secara garis besar suku para responden dalam penelitian ini adalah Jawa (91,5\%) dan beragama Islam $(82,4 \%)$ sehingga tidak bisa digeneralisasi dan peneliti belum menemukan referensi yang mendukung.

Data mengenai diskusi dengan pasangan sebelum melakukan tes HIV dapat dilihat pada tabel 2 di mana 185 wanita $(56,2 \%)$ melakukan diskusi terlebih dahulu dengan pasangan seksualnya sebelum tes HIV. Hasil uji multivariat (tabel 5) didapatkan bahwa diskusi dengan pasangan merupakan hal yang berhubungan dengan keterbukaan. Hal ini sesuai dengan penelitian yang dilakukan oleh Alemayehu et al (2014); Deribe, Lingerh, dan Dejene $(2005)^{13}$ dan Seid et al (2012) ${ }^{12}$ yang menyatakan bahwa wanita yang melakukan diskusi dengan pasangan seksualnya terlebih dahulu sebelum tes HIV akan lebih terbuka mengenai statusnya pada pasangan seksualnya. Hal ini dapat disebabkan karena komunikasi terutama pada pasangan merupakan kunci utama untuk 
mengantisipasi reaksi pasangan dan akan memberikan harapan bagi hubungan mereka untuk tetap bertahan serta berterus terang akan hasilnya pada orang lain di kemudian hari ${ }^{7}$.

Distribusi responden berdasarkan sexual experiences dan faktor terkait sexual experiences wanita penderita HIV/AIDS di LSM Victory Plus dapat dilihat di tabel 3. Tipe pasangan seksual merupakan hal yang berhubungan dengan keterbukaan status HIV seropositif. Hal ini sesuai dengan penelitian yang dilakukan oleh $\mathrm{Vu}$ et al (2012) ${ }^{14}$ yang menemukan bahwa wanita dengan pasangan steady 2,7 kali lebih terbuka mengenai status HIV-nya dibandingkan dengan pasangan casual. Dalam penelitian ini, hasil uji multivariate untuk tipe pasangan seksual didapatkan aOR 0,191, tidak setinggi hasil yang didapatkan oleh $\mathrm{Vu}$ et al (2012). ${ }^{14}$ Tipe pasangan berhubungan dengan keterbukaan status HIV karena pada pasangan casual, seseorang akan merasa kurang bertanggung jawab atas keadaan pasangannya. ${ }^{13} \mathrm{Hal}$ ini dapat disebabkan karena hubungan dengan pasangan casual apalagi tanpa status pernikahan dianggap sebagai suatu hubungan yang tidak stabil.

Pada hubungan pasangan steady, seseorang akan merasa peduli dengan kondisi kesehatan pasangan dan merasa bertanggung jawab untuk melindungi pasangannya dari penyakit HIV/AIDS, salah satunya dengan berterus terang. ${ }^{15}$ Hubungan steady juga dianggap sebagai suatu hubungan yang solid di mana permasalahan terkait pengasuhan anak, dukungan terhadap kebutuhan anak serta pencarian nafkah menjadi permasalahan bersama terutama saat nanti menghadapi situasi di mana salah satu pasangan tidak mampu melakukan tugasnya karena sakit. ${ }^{17}$ Pasangan steady juga kebanyakan tinggal dalam satu rumah, sehingga akan sulit bagi seorang wanita untuk menyembunyikan status dari pasangannya serta di sisi lain, pasangan steady biasanya merupakan orang terdekat dan paling dipercaya dari responden untuk saling berbagi. ${ }^{17}$ Dari penelitian yang dilakukan oleh $\mathrm{Vu}$ et al (2012) juga didapatkan bahwa wanita sebetulnya dua kali lebih mungkin untuk terbuka mengenai statusnya dibandingkan laki-laki. Namun dalam hal ini, ketimpangan sebuah hubungan casual menjadikan wanita tidak bisa leluasa menanyakan status HIV pasangan dan pria juga merasa tidak ada kewajiban untuk mejawab atau terbuka mengenai status HIV pada dirinya .

Pengetahuan mengenai status pasangan seksual juga merupakan variabel yang berhubungan setelah dilakukan uji multivariat dengan aOR 0,036; $95 \% \mathrm{Cl}$; 0,008-0,160. Penelitian menemukan bahwa orang dengan HIV/AIDS cenderung untuk terbuka mengenai statusnya pada pasangan seksual yang juga terbuka mengenai statusnya. Satu penjelasan yang mungkin 
mengenai hal ini adalah saat seseorang mengetahui mengenai status HIV pasangannya maka akan dibutuhkan diskusi lanjutan mengenai status dari dirinya sendiri bersama dengan pasangannya tersebut terkait hubungan seksual selanjutnya yang akhirnya akan membawa kepada keterbukaan status HIV pada keduanya. ${ }^{17}$ Jika satu orang tidak berani menanyakan, maka bisa jadi pasangan juga tidak akan bercerita. Penemuan ini mengindikasikan bahwa bukan status HIV yang menentukan terbuka atau tidaknya seseorang akan status HIVnya, tapi lebih ke arah seseorang lebih mau terbuka saat mengetahui status HIV pasangannya. $^{14} \mathrm{Hal}$ ini memiliki implikasi bahwa kemampuan negosiasi terhadap pasangannya sebelum melakukan hubungan seksual dan mengetahui status HIV pasangan sebelum melakukan hubungan seksual merupakan hal yang sangat vital mengingat hal ini ternyata dapat digeneralisasikan pada hampir semua populasi.

Data mengenai keterbukaan status HIV seropositif pada wanita dengan HIV/AIDS di LSM Victory Plus Yogyakarta dapat dilihat pada tabel 4 di mana tingkat keterbukaan wanita penderita HIV/AIDS di LSM Victory Plus Yogyakarta termasuk kategori tinggi $(79,4 \%)$ walaupun tidak setinggi beberapa penelitian yang pernah dilakukan sebelumnya yaitu di Amerika Serikat oleh Stirrat et al (2006) sebesar 82\%, di Kemisie Health Center oleh Seid et al (2012) sebesar 93,1\%, di Hawassa referral Hospital oleh Taye, Dereje, dan Endrias (2010) sebesar 85,7\%, dan di California oleh Dave et al (2006) sebesar 100\%.

Dari tabel 4 didapatkan juga waktu yang diperlukan oleh seseorang untuk terbuka terhadap pasangan adalah lebih dari 6 bulan (44,3\%) dengan waktu pendekatan lebih dari 1 bulan $(62,6 \%)$, lebih memilih terbuka saat menjalani ART (81,7\%) dan alasan terbesar kenapa mau membuka status HIV seropositifnya adalah karena melihat orang lain (dalam hal ini termasuk pasangannya) terbuka mengenai status HIV seropositifnya. Sedangkan alasan para wanita yang tidak mau terbuka mengenai status HIV seropositifnya adalah karena takut ditolak pasangannya $(44,7 \%)$ dan takut stigma masyarakat $(35,9 \%)$.

\section{KESIMPULAN}

Hasil penelitian ini menyimpulkan bahwa tingkat keterbukaan status HIV seropositif pada wanita dengan HIV/AIDS di LSM Victory Plus Yogyakarta relatif tinggi yaitu $79,4 \%$ dengan alasan terbesar para wanita untuk terbuka adalah dukungan pasangan. Faktor-faktor yang berhubungan dengan keterbukaan status adalah suku, agama, diskusi dengan pasangan sebelum tes HIV, tipe pasangan seksual, dan pengetahuan mengenai status HIV pasangan seksual. Sedangkan dari $20,4 \%$ wanita yang 
tidak terbuka, alasan terbesar adalah takut ditolak pasangannya $(44,7 \%)$ dan takut stigma masyarakat (35,9\%).

Hasil penelitian ini dapat digunakan oleh wanita penderita HIV/AIDS sebagai bahan pertimbangan untuk terbuka terhadap pasangan seksualnya dan upaya pencegahan dan penyebaran HIV/AIDS yang lebih luas.

\section{TERIMA KASIH}

1. L2DIKTI Wilayah V, Jalan Tentara Pelajar No 13. Yogyakarta. 55231. Telp: (0274) 513538. Email: Ildikti5@ristekdikti.go.id

2. Yayasan Victory Plus. Jl Tunggorono, No. 5, Mrican, Caturtunggal, Kec. Depok, Kabupaten Sleman, Daerah Istimewa Yogyakarta 55283. Telp: (0274) 587064. Email: victoryplus2004@yahoo.com

\section{KEPUSTAKAAN}

1. Rodrigo,R \& Rajapakse,S. Current status of HIV/AIDS in south asia. Journal of global infection disease. 2009. Vol 1. Issue 2.

2. Piot, $P$ and Quinn, TC. Response to The AIDS Pandemic - A Global Health Model.N Engl J Med.2013;368:2210-8.

3. DiClemente,R.J., $\quad$ Critenden,C.P., Rose,E., Sales,J.M., Winggood,G.M., Crosby,R.A., \& Salazar,L.F. Psychosocial predictors of HIV - associated sexual behaviors and the efficacy of prevention intervention in adolescent at risk for HIV infection: What works and what doesn't work?. Psychomatic Medicine,70,598605.2008. Tersedia dalam http://dx.doi.org/10.1097/PSY.0b013e318 1775edb diakses tanggal 02 Februari 2016.
4. Kementrian Kesehatan Republik Indonesia (Kemenkes RI). Situasi dan Analisis HIV AIDS. 2014. tersedia dalam http://www.depkes.go.id/resources/downl oad/pusdatin/infodatin/Infodatin\%20AIDS. pdf diakses tanggal 02 Februari 2016.

5. Burnet Institute. Partner Notification of sexually transmitted infections in New South wales: an informed literature review. 2010. Tersedia dalam: http://stipu.nsw.gov.au/wpcontent/uploads/NSW STI PN PDF.pdf diakses tanggal 02 Februari 2016

6. Minson,J. The Influence of HIV Stigma and Disclosure on Psychosocial Behavior .2011. tersedia dalam http://scholarworks.waldenu.edu/cgi/viewc ontent. cgi?article $=2153 \&$ context $=$ dissertat ions diakses tanggal 02 februari 2016

7. Alemayehu, A. ,Aregay,A., Kalayu and Yebyo,H. HIV Disclosure to Sexual partner and associated factors among women attending ART Clinic at Mekelle hospital, Northern Ethopia. BMC Public Health. 2014,14:746

8. Stirratt,MJ., Remien,RH., Smith,A., Copeland,OQ., Dolezal,C., Krieger,D. The role of HIV serostatus disclosure in antiretroviral medication adherence. AIDS Behavior. 2006, 10(5): 483-93. 10.1007/s10461-006-9106-6

9. Larkins,S., Reback, C.J., Shoptaw, S., Veniegas, R. Methamphetaminedependent gay men's disclosure of their HIV status to sexual partners. AIDS Care.2005, 17:521-532. [PubMed] 10.1080/09540120512331314321

10. Kalichman,S.C., and Nachimson,D.Selfefficacy and disclosure of HIV positive sero status to sex partners. Health Psychol.1999, 18:281-287.

11. Chin,D.,and Kroesen,K.W. Disclosure of HIV Infection Among Asian/Pacific Islander American Women: Cultural Stigma and Support. Cultural Diversity and Ethnic Minority Psychology. 1999. Vol. 5, No. 3, 222-235

12. Seid,M., Wasie,B., Admassu,M. Disclosure of HIV positive result to a sexual partner among adult clinical service users in kemissie district, 
northeast Ethopia. African Journal of Reproduction Health,March 2012: 16(1):97

13. Deribe K, Woldemichael K, Wondafrash M, Haile A, Amberbir A. Disclosure experience and associated factors among HIV positive men and women clinical service users in Southwest Ethiopia. BMC Public Health.2008.8: 81. doi: 10.1186/1471-2458-8-81.

14. Vu,L., Andrinopoulos,K., Mathews,C., Chopra,M., Kendall,C., Eisele,T.P. Disclosure Of HIV Status To Sex Partners Among HIV Infected Men And Women In Cape Town,South Africa. AIDS Behav.2012. 16:132-138.DOI 10.1007/s10461-010-9873-y

15. Wolitski,RJ., Bailey,CJ, Leary,A., Gomez,CA., Parsons,JT. Self-Perceived Responsibility of HIV Seropositive Men Who Have Sex With Men For Preventing HIV Transmission. AIDS and Behavior. December 2003. Volume 7; Issue; pp363372.

16. Miller,AN \& Rubin,DL. Factors leading to self-disclosure of a positive HIV diagnosis in Nairobi, Kenya. Qualitative Health

Research. 2007; 17;pp586-598 